\title{
Non-ethical Behaviour Mediates Relationship of Rules Obedience, Management Morality, and Effectiveness of Internal Monitoring System towards Accounting Fraud Tendency
}

\author{
Muhammad Yamin Noch ${ }^{1}$, Victor Pattiasina ${ }^{1}$, Yohanes Cores Seralurin ${ }^{1}$ and Fighty Elia Ratag ${ }^{1}$ \\ \{1abienoch12@gmail.com, ${ }^{2}$ victor_pattiasina@uniyap.ac.id, 3joecores@yahoo.co.id, \\ 4fighty3891@gmail.com\}
}

${ }^{1}$ YAPIS Papua University, Dr. Samratulangi Street No. 11 Mandala North Jayapura Indonesia

\begin{abstract}
This research was conducted to examine impact of rules obedience, management morality, and effectiveness of internal controls, towards Accounting Fraud Tendency, which mediated by unethical behaviour in Regional Devices Organization (RDO) at Keerom regency, Papua. Data was obtained through questionnaire and was analysed using path analysis through the assistance of SPPS computer program version 23.0. The results showed that obedience towards accounting rules and management morality has got positive and significant impact towards accounting fraud tendency. The effectiveness of internal management system has got positive impact, but not significant, towards accounting fraud tendency. The impact of non-ethical behaviour as intervening between management morality and accounting fraud tendency was not dominant. In other side, non-ethical behaviour, as intervening between accounting obedience and effectiveness of internal management system, towards accounting fraud tendency, has not got dominant impact.
\end{abstract}

Keywords: Rules Obedience, Management Morality, Internal Monitoring System (IMS), IMS Effectiveness, Non-ethical Behaviour, Accounting Fraud Tendency, Fraud

\section{Introduction}

Transparency International (TI) has released corruption perception index for year 2017. Indonesia was a country with a corrupt ranked 96 in the world (Hardoko, 2017). Indonesia Corruption Watch (ICW) in year 2017 noted 9 (nine) provinces with highest corruption cases. They were East Java, West Java, North Sumatra, Aceh, Central Java, Riau, South Sulawesi, West Nusa Tenggara, and Riau Islands (Watch, 2017).

In other side, by the year of 2016, ICW also detected the fraud potential in the area of services and goods procurement. For most potential fraud regency, Keerom regency in Papua was the first risk regency with an average score 15.7. There were 56 procurement projects with given budget Rp. 161, 75 billion (Mashabi, 2017).

The manipulation of financial data was acted by a particular party for its own or private benefits (Mashabi, 2017). Generally, tendency of accounting fraud is related to corruption (Mashabi, 2017). In corruption, there were unusual actions performed, such as manipulating the recording, the disappearance of documents, and mark-up that causes losses of state economy. Therefore, internal control is very important. It provides protection for the entity towards human foibles as well as to reduce the possibility of errors and actions that do not comply rules (Mashabi, 2017). Based on above consideration, the authors conducted this research under the topics of Non-ethical Behaviour Mediates Rules Obedience Relationship, 
Management Morality, and Effectiveness of Internal Monitoring System towards Accounting Fraud Tendency.

\section{Literature Review}

This research is based on Attribution theory. Attribution is a process for interpreting events, reasons, or background of person's behaviour (Mashabi, 2017). The theory stated that person's behaviour and the reasons of why someone does something, is caused by internal factors or external factors. Based on the statement above, it can be concluded that the attribution theory describes the effort to understand causes behind behaviour of others (Mashabi, 2017).

Behaviour that caused by internal factors is behaviours that believed to be under the control of, or comes from the individual itself (Mashabi, 2017), such as personality traits, motivation or ability. Behaviour that caused by external factors is behaviour that believed to be the result of outside causes, or comes from outside of individual, such as equipment, or social influence from others (Mashabi, 2017). Both are related to accounting fraud behaviour.

Accounting Fraud is one of the actions that intentionally made by an actor, in order to gain personal profit (Mashabi, 2017). Factors that drive someone to commit fraud are: 1) Pressure, 2) Opportunity, and 3) Rationalization (Zainal, 2013). An agency or institution will behave non-ethically and take actions of cheating since it does not commit or not obey to an accounting rules. Agency theory states that committing accounting rules will minimize fraudulent behaviour (Mashabi, 2017), while failure in processing financial statements is cause by management disobedience to the accounting rules. This will also cause fraud that cannot be detected by the auditor (Mashabi, 2017).

A study conducted by Pradyani showed that morality has no impact towards fraud accounting. The higher stages of management morality, the more management notices a wider and more universal interest that not focus on fraud activity. (Mashabi, 2017). Whether the morality of management is high or low, possibility of cheating can still occur (Mashabi, 2017). However, non-ethical behaviour could eventually increase the occurrence of accounting fraud tendency, which will inflict financial loss of organization (Mashabi, 2017).

Furthermore, the effectiveness of Internal Monitoring System (IMS) will affect transactions tests, balance sheets detail test, fraud detection activity, and incidence of fraud. The more effective of IMS, the lower fraud incidence happens (Mashabi, 2017). Non-ethical behaviour and other deviant behaviours can be decreased by the existence of effective IMS in a management (Mashabi, 2017).

To examine this research issues, authors conducted quantitative research. Population in this research was 52 Regional Devices Organization (RDO) in Keerom regency, by year 2018. Location was chosen based on the consideration that the area is potentially committing fraud accounting (Mashabi, 2017). Data collection in this research applied questionnaires technique. Total samples were 104 respondents.

\section{Result And Discussion}

From 104 distributed questionnaires, there were only 98 questionnaires that could be received back. After examining the 98 questionnaires that have been received back, it was found that 13 questionnaires could not be used. The questionnaires were not used since the response that answered in the questionnaire respondents did not complete. Therefore, total questionnaires that could be processed were only 85 questionnaires. In analysing research data, the authors applied path analysis technique. It was applied using SPSS program 23. 
In the test path analysis, it has got some basic principles, namely linearity and the normality of research data. (Mashabi, 2017). Based on that assumption, the authors firstly conducted examination towards the fulfilment of assumption basic principles to meet path analysis conditions.

Linearity test applied Langrage Multiplier test that conducted by regressing independent variable in residual value of the equation (Mashabi, 2017). Linearity assumption will be fulfilled if $\mathrm{c}^{2}$ count is smaller than $\mathrm{c}^{2}$ table. Following is the table of linearity test result.

Table 1. Linearity Test Result

\begin{tabular}{llll}
\hline Equation & $\mathbf{C}^{\mathbf{2}}$ count & $\mathbf{C}^{\mathbf{2}}$ table & Note \\
\hline First & 67,17 & 107.52 & Linear \\
\hline Second & 50.74 & 107.52 & Linear \\
\hline Third & 69.23 & 107.52 & Linear \\
\hline
\end{tabular}

Based on that table, it can be justified that the models created can be applied for examining the next path analysis. After that, the authors conducted test for normality. It aims to examine whether the variable regression model in the residual has got a normal distribution or not. In this research, test of normality was conducted with a normal probability plot graph analysis (test of normal probability plot graph was conducted by the assistance of SPSS program 23). By watching the tension of data spread towards regression line, it was found that there was no cluster plot data located far of normality test line. Test graph result of normal probability plot has justified that data in this study have got a normal distribution.

The hypothesis proposed in this study was examined by applying path analysis to prove whether there was causal relationship between exogenous variables and endogenous variables or not. The equation is as follows:

\begin{tabular}{llll}
\hline First equation & $:$ & $X_{3}:$ & $\beta_{1} X_{1}+\beta_{2} X_{2}+\varepsilon_{1}$ \\
\hline Second equation & $:$ & $Z$ & $\beta_{1} X_{1}+\beta_{2} X_{2}+\beta_{3} X_{3}+\varepsilon_{2}$ \\
\hline Third equation & $:$ & $Y$ & $\beta_{1} X_{1}+\beta_{2} X_{2}+\beta_{3} X_{3}+\varepsilon_{3}$ \\
\hline
\end{tabular}

First equation can be examined by following table

Table 2. The Impact of Rules Obedience (X 1) and Management Morality (X 2) towards the Effectiveness of IMS (X 3)

\begin{tabular}{lllll}
\hline $\begin{array}{l}\text { Bound } \\
\text { Variabl } \\
\text { es }\end{array}$ & $\begin{array}{l}\text { Free } \\
\text { Varia } \\
\text { bles }\end{array}$ & $\begin{array}{l}\text { Coefficien } \\
\text { ts } \\
\text { Compone } \\
\text { nt Beta }\end{array}$ & $\begin{array}{l}\text { The } \\
\text { value } \\
\text { of t }\end{array}$ & Sig \\
\hline $\mathrm{X}_{3}$ & $\mathrm{X}_{1}$ & 0.407 & 3.158 & 0.002 \\
\cline { 2 - 5 } & $\mathrm{X}_{2}$ & 0.495 & 3.841 & 0.000 \\
\hline $\mathrm{R}$ & 0.884 & & \\
\hline $\mathrm{R}_{\text {Square }}$ & & 0.781 & & \\
\hline $\begin{array}{l}\text { Adjusted } \\
\text { Square }\end{array}$ & $\mathrm{R}$ & 0.775 & & \\
\hline $\mathrm{t}_{\text {table }}$ & & 1.662 & & \\
\hline
\end{tabular}


Coefficient $\beta_{1} X_{1}=0.407$ indicated that each rules obedience value has increased or has been better. Therefore the value of the effectiveness of IMS would be increased by the value of the regression coefficient $\beta_{1} X_{1}$. Coefficient $\beta_{2} X_{2}=0.495$ indicated that each management morality value has increased or has been better. Therefore the value of the effectiveness of IMS would be increased by the value of the regression coefficient $\beta_{2} X_{2}$. In other words, each increasing of IMS effectiveness required management morality value of 0.495 , by the assumption that IMS effectiveness was stable. In second equation, the path analysis results on the impact of rules obedience $\left(\mathrm{X}_{1}\right)$, management morality $\left(\mathrm{X}_{2}\right)$, and the effectiveness of IMS $\left(\mathrm{X}_{3}\right)$ towards non-ethical behaviour could be examined in the following table.

Table 3. Direct impact of Rules Obedience (X1), Management Morality (X 2), and The Effectiveness of IMS (X 3) towards Non-ethical Behaviour (Z)

\begin{tabular}{|c|c|c|c|c|}
\hline $\begin{array}{l}\text { Bound } \\
\text { Variables }\end{array}$ & $\begin{array}{l}\text { Free } \\
\text { Variables }\end{array}$ & $\begin{array}{l}\text { Coefficients Component } \\
\text { Beta }\end{array}$ & $\begin{array}{l}\text { The value } \\
\text { of } t\end{array}$ & Sig \\
\hline \multirow[t]{3}{*}{$\mathrm{Z}$} & $\mathrm{X}_{1}$ & 0.334 & 1.778 & 0.079 \\
\hline & $\mathrm{X}_{2}$ & 0.029 & 0.148 & 0.882 \\
\hline & $\mathrm{X}_{3}$ & 0.434 & 2.854 & 0.005 \\
\hline \multicolumn{2}{|l|}{$\mathrm{R}$} & 0.768 & & \\
\hline \multicolumn{2}{|l|}{$\mathrm{R}_{\text {Square }}$} & 0.590 & & \\
\hline \multicolumn{2}{|c|}{ Adjusted R Square } & 0.574 & & \\
\hline \multicolumn{2}{|c|}{$\mathrm{t}_{\text {table }}$} & 1.662 & & \\
\hline
\end{tabular}

Coefficient $\beta_{1} X_{1}=0.407$ indicated that each rules obedience value has been increased or has been better. Each increasing of non-ethical behaviour required rules obedience value of 0.334. Coefficient $\beta_{2} X_{2}=0.029$ indicated that each management morality value would be increased by the value of the regression coefficient $\beta_{2} X_{2}$. Coefficient $\beta_{3} X_{3}=0.434$ indicated that each value of IMS effectiveness would be increased by the value of the regression coefficient $\beta_{3} X_{3}$. In other words, each increasing of non-ethical behaviour required IMS effectiveness value of 0.434 , by assumption that non-ethical behaviour was stable. For the third equation, analysis results of rules obedience direct path impact $\left(\mathrm{X}_{1}\right)$, Effectiveness of IMS $\left(\mathrm{X}_{3}\right)$, and non-ethical behaviour $(\mathrm{Z})$ towards Accounting Fraud could be examined in the following table.

Table 4. Rules Obedience direct path impact $\left(\mathrm{X}_{1}\right)$, Effectiveness of IMS $\left(\mathrm{X}_{3}\right)$, and Nonethical Behaviour $(\mathrm{Z})$ towards Accounting Fraud $(\mathrm{Y})$

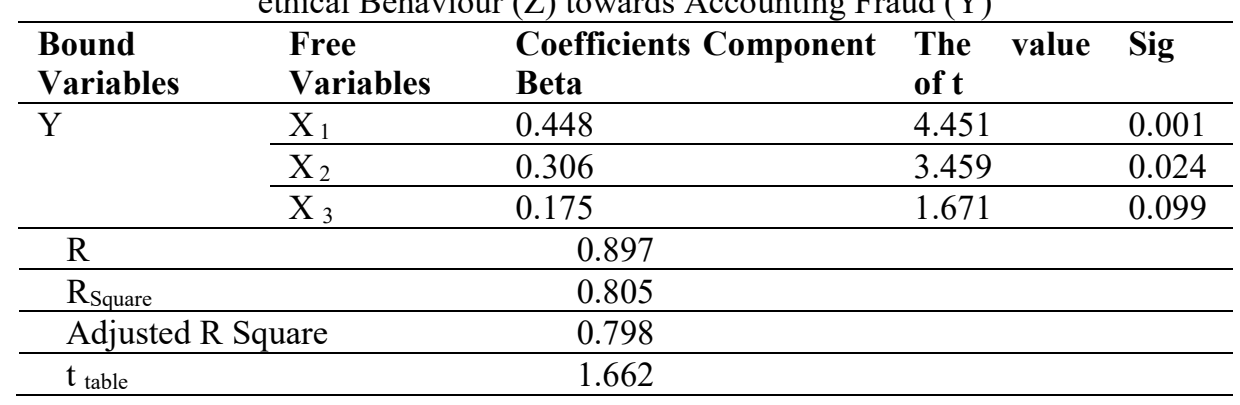

Coefficient $\beta_{1} \mathrm{X}_{1}=0.448$ indicated that value of accounting fraud tendency would be increased by the value of the regression coefficient $\beta_{1} X_{1}$. In other words, each increasing of 
accounting fraud tendency required rules obedience value of 0.448 . Coefficient $\beta_{2} X_{2}=0.306$ indicated that each Effectiveness of IMS value has increased or has been better, and the value of accounting fraud tendency would be increased by the value of the regression coefficient $\beta_{2} X_{2}$. In other words, each increasing of accounting fraud tendency required IMS value of 0.306 .

Coefficient $\beta_{3} X_{3}=0.175$ indicated that each value of non-ethical behaviour has increased or has been better. The value of accounting fraud tendency would be increased by the value of the regression coefficient $\beta_{3} X_{3}$. In other words, each increasing of accounting fraud tendency required non-ethical behaviour value of 0.175 , by the assumption that non-ethical behaviour was stable. Next, prediction towards the entire line coefficients that modelled on this research could be examined in the following summary of path coefficients results.

Table 5. Summary of the Path Coefficients Results

\begin{tabular}{|c|c|c|c|c|}
\hline $\begin{array}{l}\text { Exogeno } \\
\text { us } \\
\text { Variable }\end{array}$ & $\begin{array}{l}\text { Endogeno } \\
\text { us } \\
\text { Variable }\end{array}$ & $\begin{array}{l}\text { Standardi } \\
\text { zed } \\
\text { Coefficien } \\
\text { t }\end{array}$ & SIG & $\begin{array}{l}\text { Not } \\
\text { e }\end{array}$ \\
\hline $\begin{array}{c}\text { Rules } \\
\text { Obedienc } \\
\text { e }\left(X_{1}\right)\end{array}$ & $\begin{array}{l}\text { Effectiven } \\
\text { ess of } \\
\text { Internal } \\
\text { Control } \\
\text { System (X } \\
\text { 3) }\end{array}$ & 0.407 & $\begin{array}{l}0.00 \\
2\end{array}$ & $\begin{array}{l}\text { Sig } \\
\text { nifi } \\
\text { cant }\end{array}$ \\
\hline $\begin{array}{c}\text { Rules } \\
\text { Obedienc } \\
\text { e }\left(\mathrm{X}_{1}\right)\end{array}$ & $\begin{array}{l}\text { Non- } \\
\text { ethical } \\
\text { Behavior } \\
\text { (Z) }\end{array}$ & 0.334 & $\begin{array}{l}0.07 \\
9\end{array}$ & $\begin{array}{l}\text { Insi } \\
\text { gnif } \\
\text { ican } \\
t\end{array}$ \\
\hline $\begin{array}{c}\text { Rules } \\
\text { Obedienc } \\
\text { e }\left(\mathrm{X}_{1}\right)\end{array}$ & $\begin{array}{l}\text { Accountin } \\
\text { g Fraud } \\
\text { Tendency( } \\
\text { Y) }\end{array}$ & 0.448 & $\begin{array}{l}0.00 \\
1\end{array}$ & $\begin{array}{l}\text { Sig } \\
\text { nifi } \\
\text { cant }\end{array}$ \\
\hline $\begin{array}{c}\text { Manage } \\
\text { ment } \\
\text { Morality } \\
\left(\mathrm{X}_{2}\right)\end{array}$ & $\begin{array}{l}\text { Effectiven } \\
\text { ess of } \\
\text { Internal } \\
\text { Control } \\
\text { System (X } \\
\text { 3) }\end{array}$ & 0.495 & $\begin{array}{l}0.00 \\
0\end{array}$ & $\begin{array}{l}\text { Sig } \\
\text { nifi } \\
\text { cant }\end{array}$ \\
\hline $\begin{array}{c}\text { Manage } \\
\text { ment } \\
\text { Morality } \\
\left(X_{2}\right)\end{array}$ & $\begin{array}{l}\text { Non- } \\
\text { ethical } \\
\text { Behavior } \\
\text { (Z) }\end{array}$ & 0.029 & $\begin{array}{l}0.88 \\
2\end{array}$ & $\begin{array}{l}\text { Insi } \\
\text { gnif } \\
\text { ican } \\
\mathrm{t}\end{array}$ \\
\hline $\begin{array}{c}\text { Manage } \\
\text { ment } \\
\text { Morality } \\
\left(\mathrm{X}_{2}\right)\end{array}$ & $\begin{array}{l}\text { Accountin } \\
\text { g Fraud } \\
\text { Tendency( } \\
\text { Y) }\end{array}$ & 0.306 & $\begin{array}{l}0.02 \\
4\end{array}$ & $\begin{array}{l}\text { Sig } \\
\text { nifi } \\
\text { cant }\end{array}$ \\
\hline $\begin{array}{l}\text { Effective } \\
\text { ness of }\end{array}$ & $\begin{array}{l}\text { Non- } \\
\text { ethical }\end{array}$ & 0.434 & $\begin{array}{l}0.00 \\
5\end{array}$ & $\begin{array}{l}\text { Sig } \\
\text { nifi }\end{array}$ \\
\hline
\end{tabular}




\begin{tabular}{|c|c|c|c|c|}
\hline $\begin{array}{l}\text { Exogeno } \\
\text { us } \\
\text { Variable }\end{array}$ & $\begin{array}{l}\text { Endogeno } \\
\text { us } \\
\text { Variable }\end{array}$ & $\begin{array}{l}\text { Standardi } \\
\text { zed } \\
\text { Coefficien } \\
\text { t }\end{array}$ & SIG & $\begin{array}{l}\text { Not } \\
\text { e }\end{array}$ \\
\hline $\begin{array}{c}\text { Internal } \\
\text { Control } \\
\text { System } \\
\left(\mathrm{X}_{3}\right) \\
\end{array}$ & $\begin{array}{l}\text { Behavior } \\
(Z)\end{array}$ & & & cant \\
\hline $\begin{array}{c}\text { Effective } \\
\text { ness of } \\
\text { Internal } \\
\text { Control } \\
\text { System } \\
\left(\mathrm{X}_{3}\right)\end{array}$ & $\begin{array}{l}\text { Accountin } \\
\text { g Fraud } \\
\text { Tendency( } \\
\text { Y) }\end{array}$ & 0.175 & $\begin{array}{l}0.09 \\
9\end{array}$ & $\begin{array}{l}\text { Insi } \\
\text { gnif } \\
\text { ican } \\
t\end{array}$ \\
\hline $\begin{array}{c}\text { Non- } \\
\text { ethical } \\
\text { Behavior } \\
\text { (Z) }\end{array}$ & $\begin{array}{l}\text { Accountin } \\
\text { g Fraud } \\
\text { Tendency( } \\
\text { Y) }\end{array}$ & 0.725 & $\begin{array}{l}0.00 \\
0\end{array}$ & $\begin{array}{l}\text { Sig } \\
\text { nifi } \\
\text { cant }\end{array}$ \\
\hline
\end{tabular}

The accuracy of hypotheses model from data $\varepsilon$ was measured by relationship of three determination coefficients $\left(\mathrm{R}^{2}\right)$ on three equations. In the first equation, value obtained was 0.225 , while in the second equation, the value obtained was 0.426 , and in the third equation, value obtained was 0.210 . Therefore, the value of the model accuracy is.

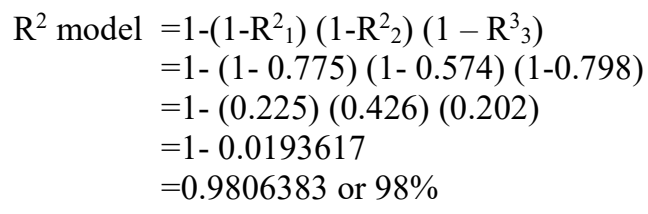

The results of accuracy calculation at the amount of $98 \%$ explained that model contribution in explaining the causal relationships of all variables examined was good

\subsection{Direct Impact of Rules Obedience}

The results of hypothesis testing revealed that the rules obedience $\left(\mathrm{X}_{1}\right)$ has got $\mathrm{t}_{\text {count }}$ value of 5.943 which was greater than $t_{\text {table }}$ value i.e. $1.662(4.451>1.662)$ with coefficient 0.448 . It means, $H a$ was received and $H O$ was rejected. In other words, it can be stated that the hypothesis was accepted. The result suggested that rules obedience has got positive and significantly impact towards the accounting fraud tendency. This means, if the rules obedience increases, then the tendency of accounting fraud will decrease. In contrary, if the rules obedience decreases, then accounting fraud tendency will increase. The result of this study is similar to result of study that conducted by Tarigan (2016). Tarigan stated that rules obedience impacted accounting fraud tendency positively (Mashabi, 2017). However, the result of this study is different to result of study that conducted by Yajna (2017). Yajna stated that rules obedience impacted accounting fraud tendency negatively. But it was quite significant (Mashabi, 2017). 
Next, analysis related to the direct impact of other rules obedience is analysis of nonethical behaviour. The results of hypothesis testing revealed that the rules obedience has got

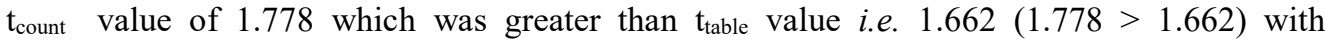
coefficient 0.334 . It means the hypothesis was accepted. The result suggested that rules obedience has got positive impact, but not significant, towards non-ethical behaviour. However, the impact is not significant. In contrary, if the rules obedience decreases, then nonethical behaviour will increase. This result is not similar to result of study conducted by (Shintadevi, 2015) (2015). (Shintadevi, 2015) stated that rules obedience has got negative impact, but significant, towards non-ethical behaviour (Mashabi, 2017).

\subsection{Direct Impact of Management Morality}

The results of hypothesis testing revealed that management morality $\left(\mathrm{X}_{2}\right)$ has got $\mathrm{t}_{\text {count }}$ value of 3.459 which was greater than $t_{\text {table }}$ value i.e. $1.662(3.459>1.662)$ with coefficient 0.175 . It means the hypothesis was accepted. The result suggested that management morality has got positive impact, and significant, towards the accounting fraud tendency. In other words, if management morality has increased, the accounting fraud tendency will be decreased.

The next examination was related to the impact of management morality towards nonethical Behaviour. It revealed that management morality $\left(\mathrm{X}_{2}\right)$ has got $\mathrm{t}_{\text {count }}$ value 0.148 , which was smaller than table value i.e. $1.662(0.148<1.662)$ with coefficient 0.029 . It can be stated that the hypothesis was rejected. The result suggested that management morality has got negative impact, and not significant, towards non-ethical behaviour.

\subsection{Direct Impact of IMS Effectiveness}

The results of hypothesis testing revealed that Effectiveness of IMS $\left(\mathrm{X}_{3}\right)$ has got $\mathrm{t}_{\text {count }}$ value of 1.671 which was greater than $t_{\text {table }}$ value i.e. $1.662(1.671>1.662)$ with coefficient 0.175. It means that Effectiveness of IMS has got positive impact, and significant, towards the accounting fraud tendency. If IMS effectiveness has increased, the accounting fraud tendency will be decreased. The result of this study is similar to result of study that conducted by Tarigan (2016). Tarigan stated that IMS effectiveness impacted accounting fraud tendency. However, the result of this study is different to result of study that conducted by Yajna (2017). Yajna stated that IMS effectiveness has negative impact, but significant, towards accounting fraud tendency.

Next, the analysis related to the direct impact of other IMS effectiveness is analysis of non-ethical behaviour. The results of hypothesis testing revealed that Effectiveness of IMS has got $t_{\text {count }}$ value of 2.854 which was greater than $t_{\text {table }}$ value i.e. $1.662(2.854>1.662)$ with coefficient 0.434 . It means that effectiveness of IMS has got positive impact, and significant, towards the accounting fraud tendency. The result of this study is similar to result of study that conducted by Tarigan (2015). Tarigan stated that effectiveness of IMS impacted non-ethical behaviour.

\subsection{Direct Impact of Non-ethical Behaviour}

The results of hypothesis testing revealed that non-ethical behaviour $(Z)$ has got $t_{\text {count }}$ value of 9.580 which was greater than $t_{\text {table }}$ value i.e. $1.662(9.580>1.662)$ with coefficient 0.725 . It means, $H a$ was received and $H O$ was rejected. In other words, it can be stated that the hypothesis was accepted. The result suggested that non-ethical behaviour has got positive and significantly impact towards the accounting fraud tendency on Regional Devices Organization 
(RDO) in Keerom regency. The result of this study is similar to result of study that conducted by (Shintadevi, 2015). (Shintadevi, 2015) stated that non-ethical behaviour has positive impact, and significant, towards accounting fraud tendency (Mashabi, 2017).

\section{Conclusion}

Based on the results of the analysis and discussion about the impact of rules obedience, management morality, and the effectiveness of IMS, towards accounting fraud tendency, with non-ethical behaviour as an intervening variable, then a conclusion can be drawn as follows

First, there was positive impact, but not significant, between rules obedience and nonethical behavior in Regional Keerom regency RDO. The rules obedience has also got positive and significant impact towards accounting fraud tendency. This could be implied that the organization should pay more attention to the rules, in order to meet specified objectives of the organization. This will also minimize the possibility of non-ethical behavior that can also refers to accounting fraud tendency.

Second, there was negative impact, but not significant, between management morality and non-ethical behavior in Kerom regency RDO. Management morality has also got positive impact, and significant, towards the accounting fraud tendency on the RDO. This contains an implication that the organization should pay more attention to management morality that can also refers to the tendency of Accounting Fraud.

Third, there was positive impact, and significant, between effectiveness of IMS towards non-ethical behavior and accounting fraud tendency in Keerom regency RDO. This could be implied that the organization should pay more attention to IMS, in order to minimize possibility of non-ethical behavior that can also refers to accounting fraud tendency.

Third, there was negative impact and not significant, between non-ethical behavior and accounting fraud tendency in Kerom regency RDO.

Fourth, the impact of non-ethical behaviour as intervening between rules obedience and accounting fraud tendency was not dominant. This statement is based on multiplication results of Rules Obedience Coefficient to Non-ethical Behavior, and multiplication results of Nonethical Behavior Path Coefficients to Accounting Fraud Tendency (0.725).

Fifth, the impact of non-ethical behavior as intervening between management morality and accounting fraud tendency was dominant. The results of the analysis showed that direct path coefficient of management morality towards accounting fraud tendency (0.306) was greater, compared to indirect path coefficient (0.021) through Non-ethical Behavior (0.306 > 0.021 , see Fig. 1 and table 4).

Sixth, the impact of non-ethical behaviour as intervening between effectiveness of IMS and accounting fraud tendency was not dominant. The results of the analysis showed that direct path coefficient of effectiveness IMS towards accounting fraud tendency (0.175) was smaller, compared to indirect path coefficient $(0.314)$ through non-ethical behaviour $(0.175<$ 0.314 .

\section{References}

[1] Hardoko, E. (2017) 'Indeks Persepsi Korupsi 2017: Peringkat Indonesia di Bawah Timor Leste', Media Online Kompas.com.

[2] Mashabi, S. (2017) 'Ini Daftar Provinsi Dan Kabupaten Dengan Potensi Kecurangan Tinggi', Media Online Merdeka.com.

[3] Shintadevi, P. F. (2015) 'Pengaruh Keefektifan Pengendalian Internal, Ketaatan Aturan Akuntansi dan Kesesuaian Kompensasi Terhadap Kecenderungan Kecurangan 
Akuntansi dengan Perilaku Tidak Etis sebagai Variabel Intervening', Nominal, Barometer Riset Akuntansi dan Manajemen, 4(2). doi: 10.21831/NOMINAL.V4I2.8003.

[4] Watch, I. C. (2017) 'Kasus Korupsi Di Provinsi', Indonesia Corruption Watch.

[5] Zainal, R. (2013) 'Pengaruh Efektivitas Pengendalian Intern, asimetri informasi Dan kesesuaian kompensasi Terhadap Kecenderungan Kecurangan Akuntansi (Fraud)', Universitas Negeri Padang, pp. 1-25. 